\title{
SHOE LAST SHAPE CUSTOMIZATION
}

\section{PERSONALIZAREA FORMEI SPATIALE A CALAPODULUI}

\author{
Mariana DRIŞCU, Mariana COSTEA* \\ "Gheorghe Asachi" Technical University of lasi, Faculty of Textile, Leather and Industrial Management, email: mpastina@tex.tuiasi.ro
}

\section{SHOE LAST SHAPE CUSTOMIZATION}

ABSTRACT. In this paper the authors present a method of modelling the shoe last shape, namely the dimensional changes in order to produce a variety of footwear products for any category of users. For this, techniques were used to model the last in work sequences of Delcam Crispin 3D application. Using specific tools of this application, modules Model Tracer and Last Maker, this paper presents techniques to create a new shoe last. One can study new shoe lasts compared to the initial ones using the Comparing function. The method for creating new lasts is useful for footwear manufacturers who can always find the shoe last according to their product or can create a new last, similar in shape or different shape from the original one.

KEY WORDS: last, parameters, heel height, toe spring, bottom length

\section{PERSONALIZAREA FORMEI SPATIALE A CALAPODULUI}

REZUMAT. În această lucrare autoarele prezintă o metodă de modelare a calapodului, respectiv modificări ale dimensiunilor acestuia pentru a se fabrica o diversitate de produse de încălţăminte, pentru orice categorie de purtători. Pentru aceasta s-au folosit tehnici pentru modelarea calapodului în secvenţe de lucru ale aplicaţiei Delcam Crispin 3D. Utilizând instrumente specifice ale acestei aplicaţiei, respectiv modulele Model Tracer şi Last Maker, în lucrare se prezintă tehnici pentru crearea unui nou calapod. Se pot studia noile calapoade comparativ cu cele iniţiale utilizând funcţia de Comparare a două calapoade. Această metodă pentru crearea unui nou calapod este utilă producătorilor de încălţăminte la realizarea de noi calapoade similare sau diferite de cel iniţial.

CUVINTE CHEIE: calapod, parametri, înălţime toc, înălţime vârf, lungime suprafaţă plantară

\section{LA PERSONNALISATION DE LA FORME POUR CHAUSSURES}

RÉSUMÉ. Dans cet article, les auteurs présentent une méthode pour la modélisation de la forme pour chaussure et des variations dimensionnelles pour produire une variété de produits de la chaussure pour toutes les catégories d'utilisateurs. Pour cela on a utilisé des techniques de modélisation de la forme dans les séquences de travail de l'application Delcam Crispin 3D. Grâce à des outils spécifiques de cette application, c'est-à-dire les modules Model Tracer et Last Maker, l'article présente les techniques pour créer une nouvelle forme. Les nouvelles formes peuvent être étudiées par rapport à l'original en utilisant la fonction de comparaison de deux formes. Cette méthode pour créer une nouvelle forme est utile pour les fabricants de chaussures dans la construction de nouvelles formes de chaussures semblables ou différentes de l'original.

MOTS-CLÉS: forme chaussures, paramètres, hauteur du talon, hauteur du pic, longueur de la surface plantaire

\section{INTRODUCTION}

The last is the most complex spatial form and is indispensable in the manufacture of footwear. Even the most experienced manufacturers of footwear products mentioned the last to be the "soul" of the footwear. Without the last there would be no footwear, no footwear industry, and no footwear fashion [1]. At the same time, they claim that the design and execution of the last is the most complex and elaborated process of the entire shoe manufacturing business, the launch pad of its manufacture [2,3].

There are no straight lines on the last. The last is made of a continuous flow of contours and configurations. In this respect, it is considered "a masterpiece of engineering and a work of art".

\section{INTRODUCERE}

Forma spaţială cea mai complexă şi indispensabilă în fabricarea încălţămintei este calapodul. Producătorii cei mai experimentaţi ai produselor de încălţăminte afirmă despre calapod că este „sufletul” încălţămintei. Fără calapod nu ar exista încălţăminte, nu ar exista industria încălţămintei, nu ar exista o modă a încălţămintei [1]. Totodată, aceştia afirmă că proiectarea ş realizarea calapodului este procesul cel mai complex şi mai minuţios din întreaga activitate de fabricare a încălţămintei, pista de lansare a fabricării acesteia [2,3].

Nu există linii drepte pe calapod. Calapodul este o continuă alunecare de contururi ş configuraţii. În acest sens, este considerat „o capodoperă a ingineriei ş o operă de artă".

* Correspondence to: Mariana COSTEA, "Gheorghe Asachi" Technical University of lasi, Faculty of Textile, Leather and Industrial Management, email: mpastina@tex.tuiasi.ro 
However, while taking into account fashion and the characteristics of each style, the contours must meet precise standards of measurement and sizing (Figure 1).

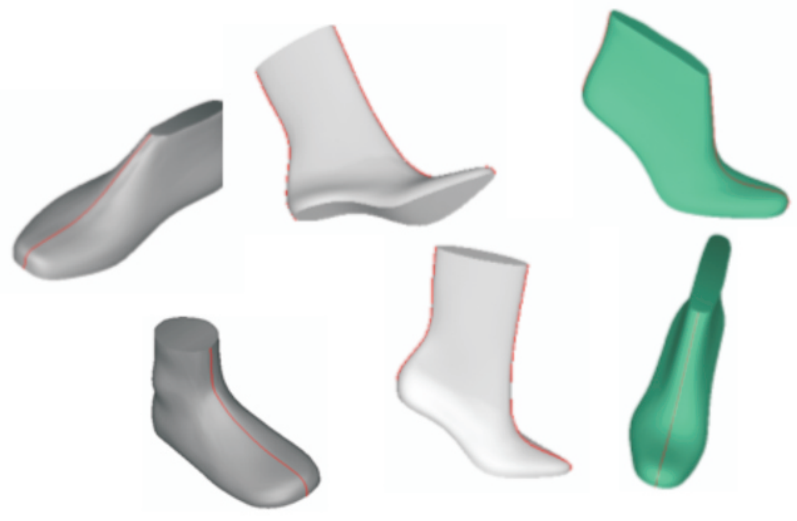

Totuşi, ţinând cont de modă ş de trăsăturile caracteristice ale fiecărui stil, aceste contururi trebuie să respecte standarde precise de măsurători ş dimensionări (Figura 1).

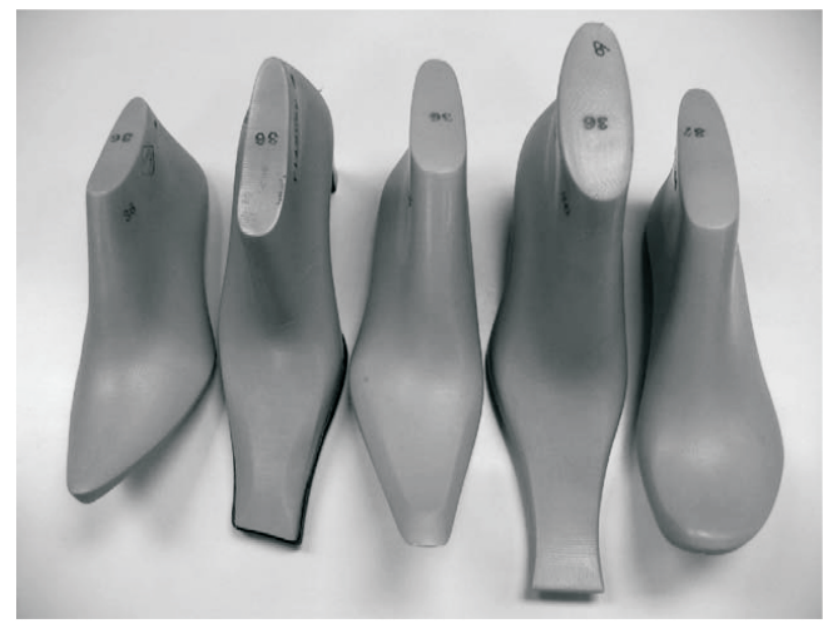

Figure 1. Different shoe last shapes

Figura 1. Diferite forme de calapoade

The process of defining the geometry of the last is a complex one. Specialists in computerized design of spatial forms state that computer-aided design of a last includes the most advanced design techniques: from defining the 3D geometry of the last to obtaining its numerical form. This enables manufacturers to make patterns and prototypes using NumericalCommand-Machines (NCM), techniques currently used in aerospace and car manufacturing industries and a number of applications requiring processing of spatial coordinates in three-dimensional shapes $[2,4$, $5,7]$.

With this purpose in mind, a series of specialized CAD/CAM software products have been developed to design lasts, with interfaces for shoe pattern production.

The paper presents some advanced methods available from CRISPIN Dynamics CAD Suite for footwear, regarding last modelling with its specific advantages. A method for customizing the last shape based on the user's foot shape was developed using the technique presented, allowing footwear manufacturers to produce footwear for all types of users.
Procesul de definire a formei geometrice a unui calapod este unul complex. Specialiştii în proiectarea computerizată a formelor spaţiale afirmă că proiectarea unui calapod cu ajutorul calculatorului cuprinde cele mai avansate tehnici de proiectare: de la definirea geometriei formei spaţiale a calapodului până la obţinerea formei numerice finale a acestuia. Acest lucru le permite producătorilor realizarea tiparelor şi a prototipurilor cu maşini cu control numeric (CNC), tehnici utilizate curent în industriile de aeronautică ş constructoare de automobile, precum şi într-o serie de aplicaţii care necesită prelucrare în coordonate spaţiale a unor forme tridimensionale $[2,4,5,7]$.

Pe această direcţie au fost elaborate o serie de produse soft CAD/CAM specializate în proiectarea calapodului, cu interfeţele necesare obţinerii tiparelor de încălţăminte.

Pentru aceasta, în continuare se prezintă metodele cele mai avansate puse la dispoziţie de sistemul CRISPIN Dynamics CAD Suite pentru încălţăminte, privind modelarea formei calapodului cu avantajele corespunzătoare. Prin tehnica prezentată s-a elaborat o metodă de personalizare a formei calapodului în funcţie de piciorul purtătorului de încălţăminte, ce permite producătorilor de încălţăminte fabricarea de produse pentru toate categoriile de purtători de încălţăminte. 


\section{METHOD}

Increasing and tougher competition among footwear producers makes market adaptability a must, one which is increasingly difficult to attain. Pricing must be carefully controlled, while the quality of the products must remain the same or even continuously improve. These requirements can be reached only by using computer-aided production. To this end, both footwear production and software companies joined forces to develop CAD/CAM shoe design software.

The design of the last influences not only how comfortably a shoe fits the foot, but also how stylish it looks. Footwear must be designed so that it perfectly fits the foot and also be comfortable. These aspects are influenced by the shape of the last, the properties of the materials, the shape of the legs, the thermal comfort of the shoe and even the shape and the colour of the upper. Using CAD/CAM systems, the producers can easily modify the shape of the lasts they already have, so that they can create new models.

Existing CAD/CAM systems allow sizing, scaling and modelling the design of the last, allowing for a personalized design to be obtained, a perfect fit of the shoe or varying the style of the last by introducing different parameters for the design. Moreover, the software takes into account the whole shape of the foot and produces parameters that allow a better fit.

This is how new lasts can be created, facilitating an increase in the quality and design of the shoe (Figure 2).

\section{METODĂ}

Competiţia tot mai acerbă între producătorii de încălţăminte şi moda în continuă schimbare face ca adaptarea la piaţă să devină o adevărată provocare. Costurile trebuie să fie controlate cu atenţie, în timp ce calitatea produselor trebuie menţinută la acelaşi standard sau chiar îmbunătăţită. Aceste elemente esenţiale ale producţiei de încălţăminte pot fi rezolvate apelând la tehnica de calcul. În acest scop producătorii de încălţăminte în colaborare cu programatori de înaltă calificare au elaborat sisteme CAD/CAM pentru fabricarea încălţămintei.

Calapodul poate influenţa potrivirea încălţămintei pe picior, confortul, dar şi stilul, şi aspectul. Încălţămintea trebuie proiectată astfel încât să se potrivească perfect pe picior şi să fie confortabilă. Confortul şi potrivirea sunt influenţate de forma calapodului, proprietăţile materialelor utilizate, forma piciorului, climatul din interiorul încălţămintei, culoarea şi forma ansamblului superior al încălţămintei. Utilizând sisteme CAD/CAM producătorii pot modifica forma calapoadelor existente pentru a crea noi modele.

Sistemele CAD/CAM existente permit dimensionarea, gradarea şi modificări asupra aspectului calapodului, ce conduc la modelarea personalizată a unui calapod, potrivirea piciorului cu calapodul sau modificarea stilului calapodului prin schimbarea valorilor parametrilor. În plus, aceste programe pot lua în calcul întreaga formă a piciorului şi asigură specificaţii pentru o mai bună potrivire a încălţămintei pe picior.

Astfel se pot modela calapoade noi ce facilitează creşterea calită̆ţii şi a aspectului încălţămintei (Figura 2).

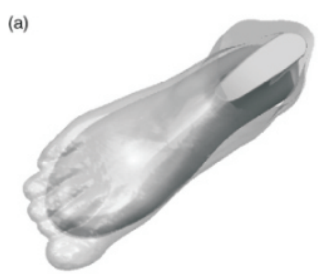

(b)
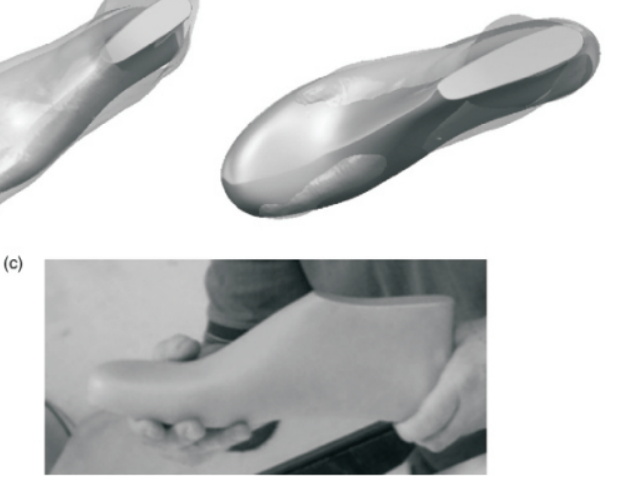

Figure 2. Customizing the shape of the last

Figura 2. Personalizarea formei calapodului 
The paper presents various ways for modelling the last, using Last Maker, a component of Delcam Crispin 3D system, using several techniques for parameter changes and for visualizing the result.

The lasts resulting from the process can be later produced using standard numerical command equipment-CNC.

\section{CRISPIN DYNAMICS - CAD SUITE}

This application has functions for creating and modifying the shoe last, making realistic designs of footwear products, flattening and transferring the base lines of the 3D model for development in $2 D[3,4]$. The software facilitates the digitization of shoe last, recentering front and back guide lines, changing foot (left/right) and setting the correct heel height. One can create guidelines to save with the last and extend the last for a boot design [3]. The last type can also be changed to a type that allows the entire last surface to be used for a design. The application is modular, as follows:

- LastMaker - a program providing the means to design and modify last width outputs to various 3D file formats.

- ShoeDesign - a program for designing uppers on 3D lasts provided by ModelTracer or LastMaker.

There are presented the most advanced methods offered by CRISPIN Dynamics CAD Suite system for footwear concerning the modelling process for the shoe last shape with the specific advantages.

\section{About Last Maker}

LastMaker - a program providing the means to design and modify lasts with outputs in various 3D file formats. This system offers new solutions for shoe makers. The system also facilities to re-centre front and back guide lines, change foot right-left (no need to redigitize), set the correct heel height and grade shoe lasts to obtain lasts for inferior and superior sizes.

This application offers functions for creating a new shoe last and setting the correct base dimensions of the shoe last using the Last>Adjust function (Figure 3 ).
Această lucrare prezintă o varietate de metode pentru modelarea calapodului, utilizând aplicaţia Last Maker, o componentă a sistemului Delcam Crispin 3D, utilizând tehnici pentru variaţia parametrilor şi vizualizarea rezultatelor.

Calapodul rezultat din acest proces poate fi trimis către maşinile CNC spre execuţia acestuia.

\section{CRISPIN DYNAMICS - CAD SUITE}

Această aplicaţie oferă funcţii pentru crearea şi modificarea calapodului, crearea celor mai realiste modele de încălţăminte, aplatizarea cu transferul liniilor de bază a modelului înscris pe calapod în plan $[3,4]$. Sistemul oferă posibilitatea digitizării calapodului, recentrarea liniilor de ghidare anterioare şi posterioare, obţinerea perechii calapodului (stâng/drept), setarea corectă a înălţimii tocului. Se pot crea linii de ghidare care se salvează împreună cu calapodul, se poate extinde calapodul pentru proiectarea unei ghete/cizme [8]. Tipul calapodului poate fi, de asemenea, modificat în funcţie de modelul ce se va proiecta. Aplicaţia este modulară, după cum urmează:

- LastMaker - un program ce furnizează comenzi pentru crearea şi modificarea calapodului cu posibilitatea exportării acestuia în diverse formate 3D.

- ShoeDesign - un program pentru crearea feţelor de încălţăminte pe calapodul 3D obţinut în ModelTracer or LastMaker.

În continuare se prezintă metodele cele mai avansate puse la dispoziţie de sistemul CRISPIN Dynamics CAD Suite pentru încălţăminte, cu privire la modelarea formei calapodului, cu avantajele corespunzătoare.

\section{Despre Last Maker}

Acest sistem oferă noi soluţii pentru producătorii de încălţăminte. Sistemul are posibilităţi de recentrare a liniilor de bază, schimbarea piciorului - drept-stâng (fără o nouă digitizare), corectarea înălţimii tocului şi gradarea calapoadelor pentru obţinerea calapoadelor de număr inferior şi superior numărului iniţial [5].

Această aplicaţie oferă funcţii pentru crearea unui nou calapod şi modificări ale dimensiunilor de bază ale calapodului utilizând funcţia Last>Adjust (Figura 3). 


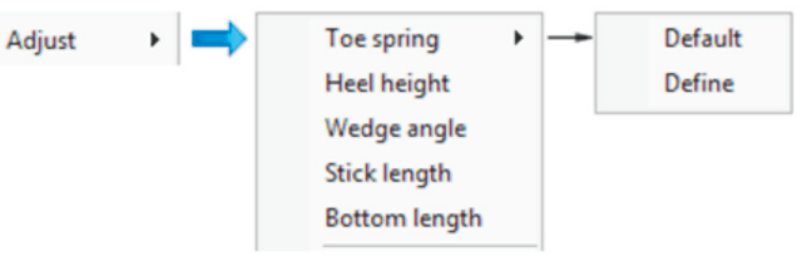

Figure 3. Last>Adjust function's menu

Figura 3. Menul funcţiei Last>Adjust

\section{Functions for Modifying the Basic Dimension of the Shoe Last}

The basic geometric parameters of the shoe last using the Adjust function are presented in Figure 4.

\section{Funcţii pentru modificarea dimensiunilor de bază a calapodului}

Dimensiunile parametrice de bază ale calapodului oferite de funcţia Adjust sunt prezentate în Figura 4.

\begin{tabular}{|l|c|}
\hline $\begin{array}{l}\text { Geometric } \\
\text { parameter }\end{array}$ & Signification \\
\hline Toe Spring & \\
\hline Heel Height & \\
\hline Stick Length & \\
\hline Bottom Length & \\
\hline Girth & \\
\hline
\end{tabular}

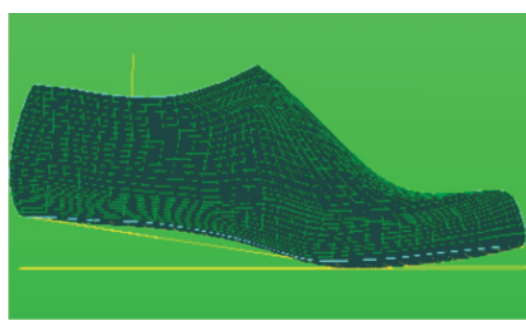

Figure 4. The basic geometric parameters of the Adjust function

Figura 4. Parametrii geometrici de bază ai funcţiei Adjust

The function for modifying the basic dimension of the shoe last is found in Table 1.

NOTE:

The paper will use English names for the 5 parameters; their significance is presented in Figure 4 and Table 1, location INSTRUMENT.
Funç̧iile şi comenzile pentru modificarea dimensiunilor de bazăalecalapoduluise regăsescîn Tabelul 1.

NOTĂ:

În lucrare se vor folosi denumirile în engleză ale celor 5 parametri, semnificaţia lor fiind prezentată în Figura 4 şi Tabelul 1, locaţia INSTRUMENT.

Table 1: The function for modifying the basic dimensions of the shoe last

Tabelul 1: Funcţii pentru modificarea dimensiunilor de bază a calapodului

\begin{tabular}{|c|c|c|}
\hline $\begin{array}{l}\text { Function } \\
\text { Funcţii }\end{array}$ & $\begin{array}{l}\text { Command } \\
\text { Comandă }\end{array}$ & $\begin{array}{l}\text { Instrument } \\
\text { Instrument }\end{array}$ \\
\hline $\begin{array}{l}\text { The function for modifying the Toe Spring } \\
\text { Funcţie pentru modificare To e Spring }\end{array}$ & Menu>Edit $>$ Last $>$ Adjust $>$ Toe Spring & \\
\hline $\begin{array}{l}\text { The function for modifying the Heel Height } \\
\text { Funcţie pentru modificare Heel Height }\end{array}$ & Menu $>$ Edit $>$ Last $>$ Adjust $>$ Heel Height & \\
\hline $\begin{array}{l}\text { The function for modifying the Stick Length } \\
\text { Funcţie pentru modificare Stick Length }\end{array}$ & Menu $>$ Edit $>$ Last $>$ Adjust $>$ Stick Length & \\
\hline $\begin{array}{l}\text { The function for modifying the Girth } \\
\text { Functie pentru modificare Girth }\end{array}$ & Menu $>$ Edit $>$ Last $>$ Adjust $>$ Girth & \\
\hline
\end{tabular}




\section{OBSERVATION}

In each function's box (Figure 5) are written the new values for each parameter.

\section{OBSERVATIE}

În caseta fiecărei funcţii (Figura 5) se înscriu noile valori pentru fiecare parametru.

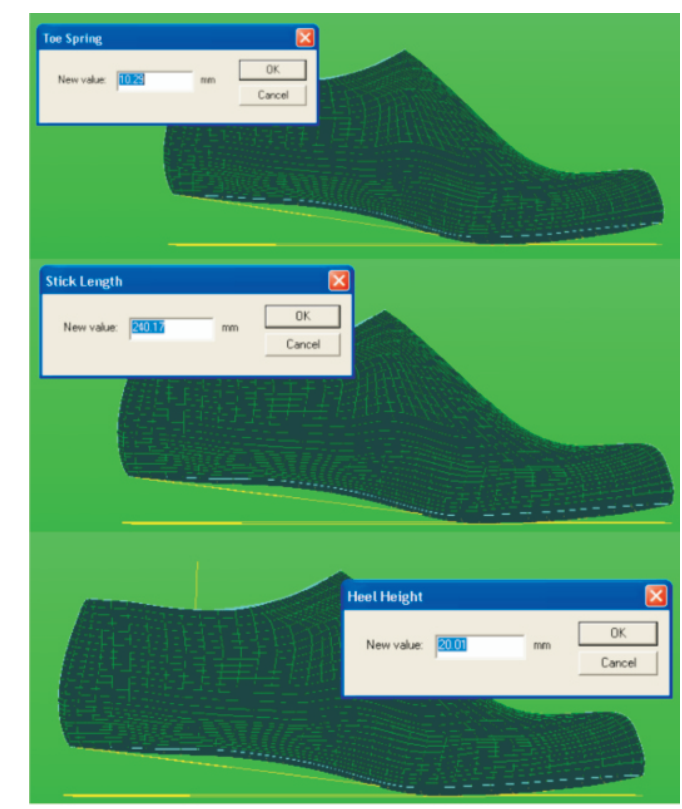

Figure 5. The window of each basic function

Figura 5. Fereastra de lucru a fiecărei funcţii de bază

\section{Comparing and Analyzing the New Shoe Last}

The comparing function allows the possibility of comparing two different lasts; the result can be measured or displayed as a solid last [3, 6-8]. First the last to be compared is opened; it is possible to have a large number of lasts opened and none of them be useful for comparison. They can easily be checked, if one selects cascade view, using the Window > Cascade function.

Now, from the main menu select: Verify > Compare > Alignment and the list of all the open files' names is brought up (Figure 6). Select the desired last and the last is opened and positioned similarly to the original last. Last positioning is the next step and various translations and rotations are required in order to properly position the toe and the back part.

\section{Compararea şi analiza noului calapod obţinut}

Această funcţie oferă posibilitatea analizei prin comparare a două calapoade diferite, rezultatul putând fi măsurat sau afişat ca un calapod solid [3, 6-8]. Se deschide prima dată calapodul ce urmează a fi comparat; este posibilă deschiderea unui număr mare de calapoade şi niciunul dintre ele nu să nu fie util în comparare. Acestea pot fi uşor verificate dacă se selectează vederea cascadă utilizând funcţia Window > Cascade.

Din meniul principal se selectează Verify > Compare > Alignment şi lista tuturor fişierelor deschise va fi adusă în prim-plan (Figura 6). Se va selecta calapodul dorit şi acesta este deschis şi orientat în mod similar calapodului original. Pasul următor este reprezentat de poziţionarea calapodului, fiind necesare translaţii şi rotaţii succesive pentru a fi încadrate în mod corespunzător vârful şi partea posterioară. 

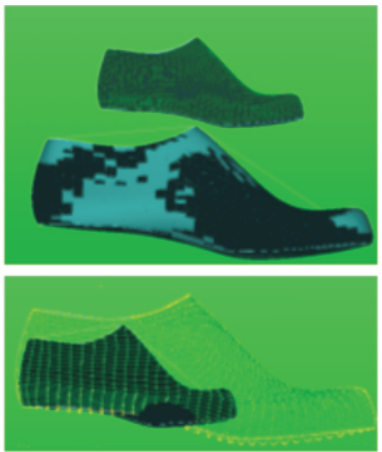
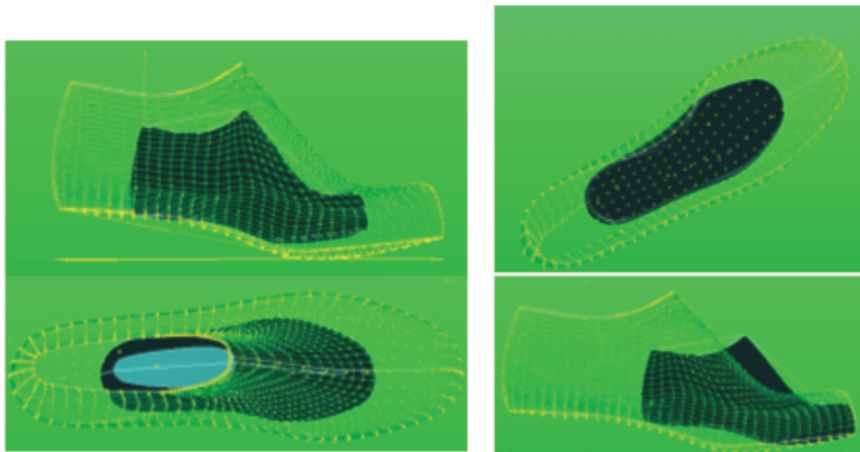

Figure 6. The result for comparing two lasts

Figura 6. Rezultatul comparării a două calapoade

\section{EXPERIMENTAL EVALUATION OF SOFTWARE PERFORMANCE}

To experimentally evaluate the work method, two different scenarios are taken into account:

- Creating a new last, similar in shape with the first last - same heel height, same shape of the tip.

- Creating a new last, with heel height different from the original one.

\section{Creating a New Last, Similar with the Original}

Let us consider two lasts of the same shape, but with different dimensions - namely Last 1 and Last 2. The dimensions for the two lasts are presented in Table 2.

\section{EVALUAREA EXPERIMENTALĂ A PERFORMANTELOR SOFTULUI}

Pentru a evalua experimental metoda de lucru, sunt luate în considerare două scenarii diferite:

- Crearea unui nou calapod, similar ca formă cu primul: aceeaşi înălţime de toc, aceeaşi formă de vârf.

- Crearea unui nou calapod cu înălţime de toc diferită de cel original.

\section{Crearea unui nou calapod similar cu cel iniţial}

Să luăm în considerare două calapoade de aceeaşi formă, dar de dimensiuni diferite, respectiv "Last 1" şi "Last 2". Dimensiunile celor două calapoade sunt centralizate în Tabelul 2.

Table 2: The results for creating a new last, similar with the original

Tabelul 2: Rezultatele creării unui nou calapod, similar cu cel original

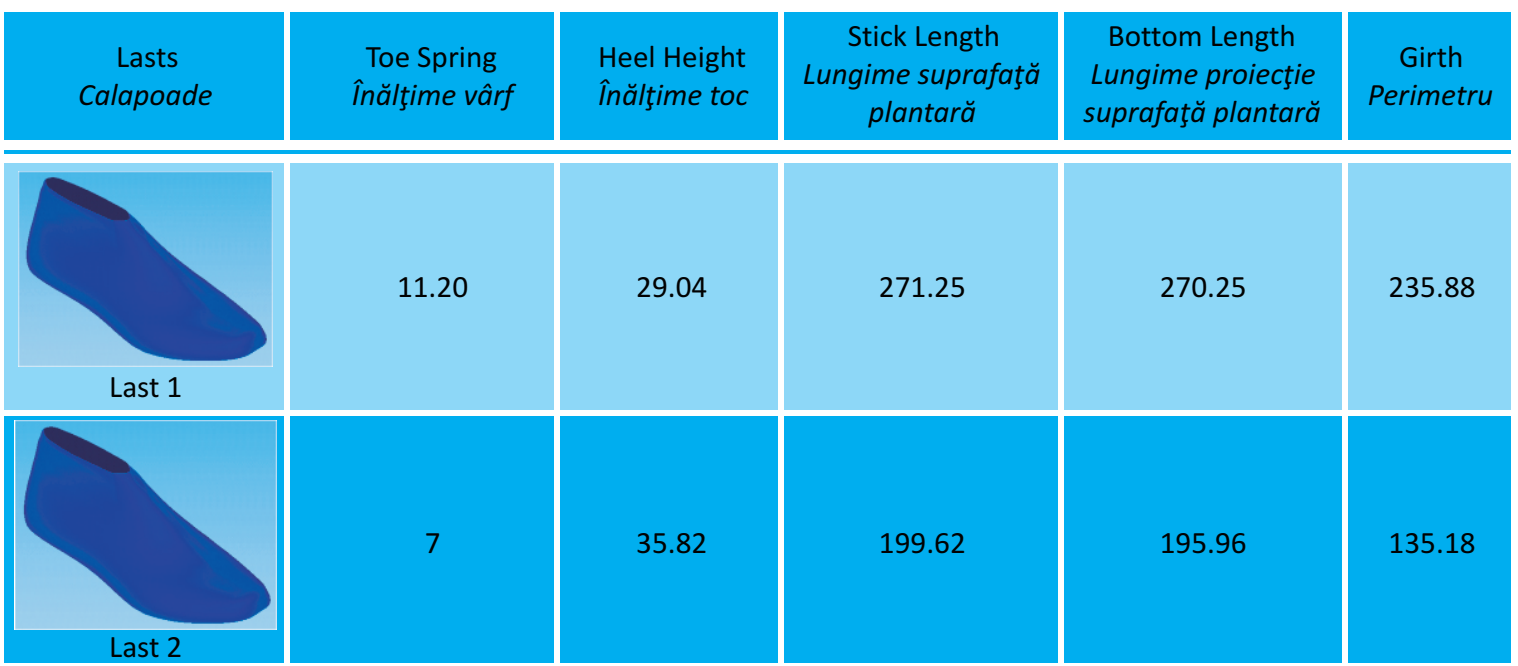


The comparative results obtained for modifying the first last with the dimensions corresponding to the second last are presented in Figure 7.
Rezultatele comparative obţinute pentru modificarea dimensiunilor primului calapod cu dimensiunile corespunzătoare celui de-al doilea calapod sunt prezentate în Figura 7.

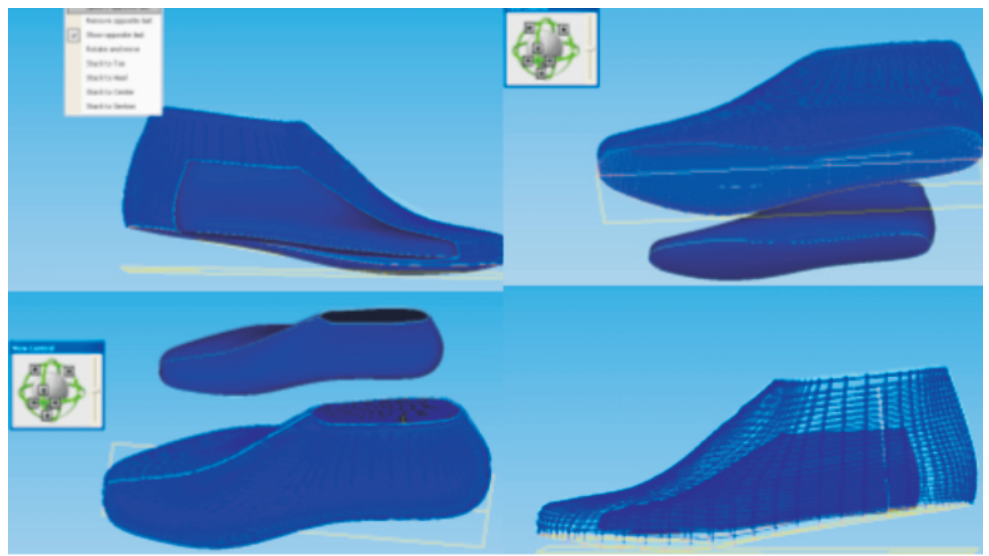

Figure 7. The results for comparing the new last, "Last 1", after modifying the parameters of this last with parameters of "Last 2"

Figura 7. Rezultate obţinute pentru compararea formei noului calapod, „Last 1", după modificarea parametrilor acestui calapod cu dimensiuni ale calapodului „Last 2"

\section{Creating a New Last with Heel Height Different from the Original One}

Let us consider two lasts of the same shape, but with different dimensions - namely "Last 3" and "Last 4".

\section{Crearea unui nou calapod cu înălţime de toc diferită de cel original}

Să luăm în considerare două calapoade de aceeaşi formă, dar cu înălţimi de toc diferite, respectiv "Last 3” şi ,"Last 4”.

Table 3: The results for creating a new last with different heel height from the original Tabelul 3: Rezultatele creării unui nou calapod cu înălţimea tocului diferită de cel original

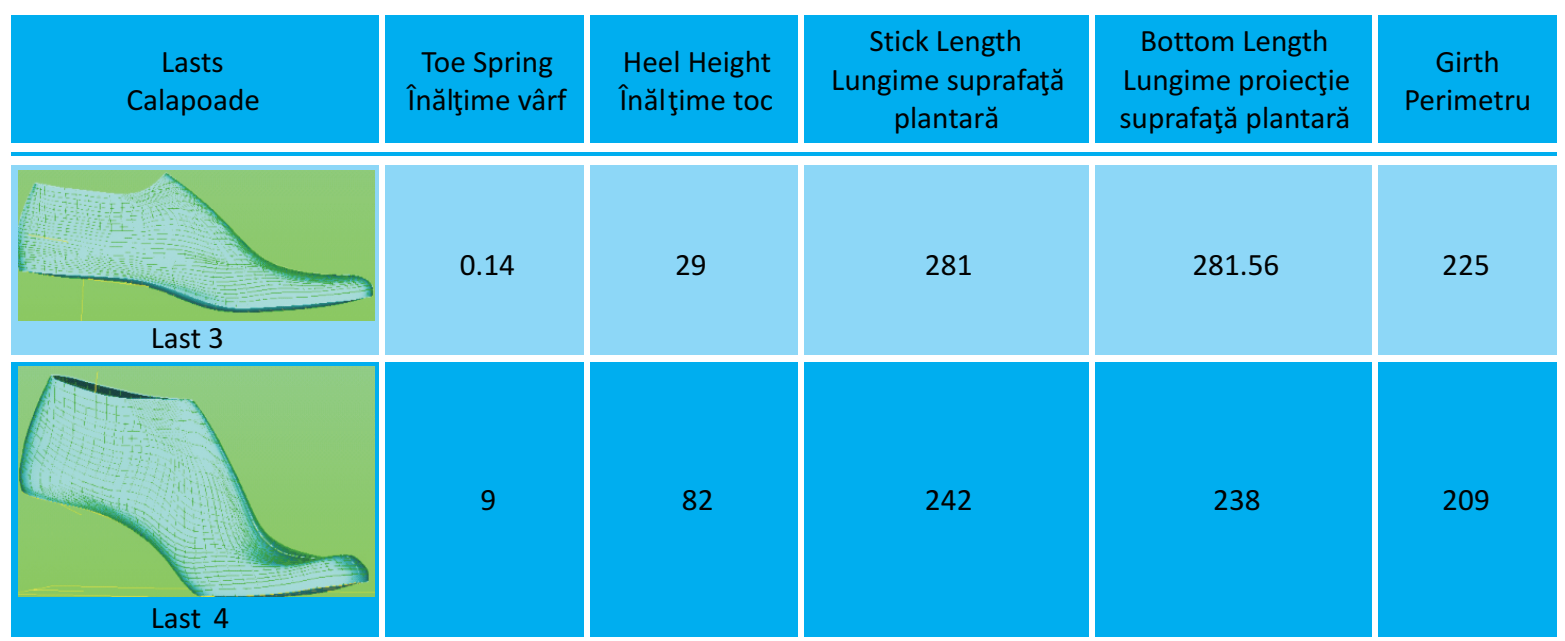


The comparative results after modifying the dimension of one last for obtaining Last 3 with dimensions of Last 4 are presented in Figure 8.
Rezultatele comparative obţinute după modificarea dimensiunilor calapodului Last $3 \mathrm{cu}$ dimensiunile calapodului Last 4 sunt prezentate în Figura 8.
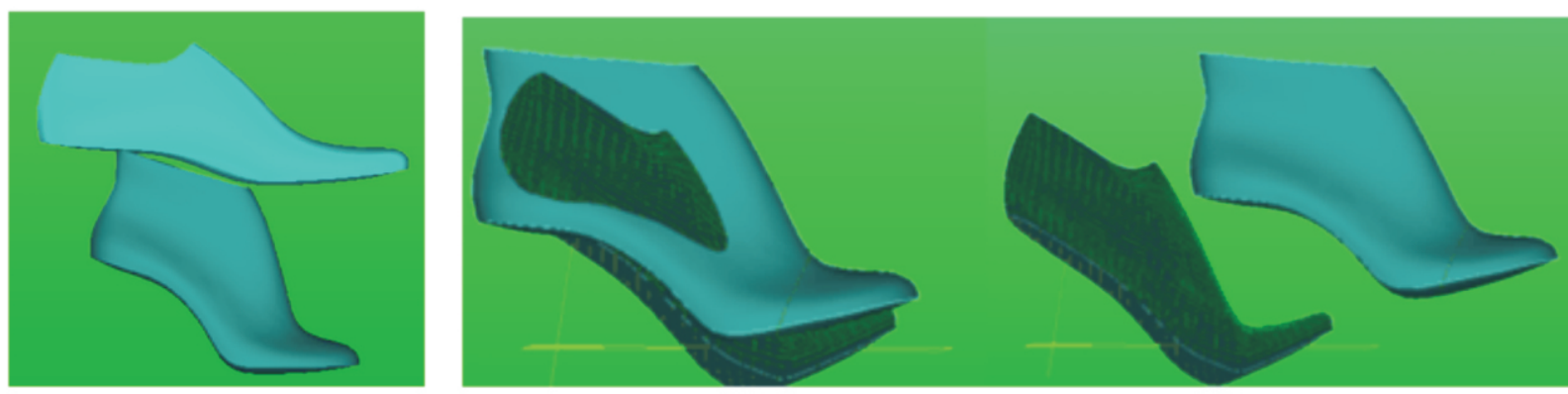

Figure 8. Comparative results after modifying the dimension of one last to obtain Last 3 with dimensions of Last 4

Figura 8. Rezultatele comparative obţinute după modificarea dimensiunilor calapodului Last 3 cu dimensiunile calapodului Last 4

\section{CONCLUSIONS}

In the past years software solutions have been developed in order to fit the shape of the last to the shape of the foot. Some of these software solutions search in a database for a last whose dimensions are as close as possible to the dimensions of the foot. There are also software solutions which allow modifying the shape of an existing last, in order to fit the shape of the foot.

The last's significance in the footwear design, modeling, and manufacturing processes is given by the fact that its shape determines the footwear shape, matching the foot and the comfort characteristics. Due to computers and computer science development in the recent years, new technologies and software applications have been developed for shoe last design, modelling and manufacture.

Using the specific tools of CRISPIN Dynamics CAD Suite software, ModelTracer and Last Maker modules, a method for creating new shoe lasts has been developed in this paper. The method can be useful for creating lasts for a variety of footwear.

The method for creating new lasts is useful for footwear manufacturers who can always find the shoe last according to their product concept.

\section{CONCLUZII}

În ultimii ani au fost dezvoltate diferite programe software pentru potrivirea formei calapoadelor cu forma piciorului. Aceste programe permit căutarea într-o bază de date cu calapoade, a unui calapod ale cărui dimensiuni sunt cât mai apropiate de dimensiunile piciorului. Sunt de asemenea programe care permit modificarea formei unui calapod preexistent pentru a coincide cu forma piciorului.

Importanţa calapodului în proiectarea, modelarea şi confecţionarea încălţămintei este dată de faptul că forma acestuia determină forma încălţămintei, rezultând astfel potrivirea cu piciorul şi asigurând confortul dimensional al acestuia. Datorită dezvoltării din ultimii ani a posibilităţilor din domeniul calculatoarelor şi al informaticii s-au realizat noi tehnologii şi aplicaţii software dedicate proiectării, modelării şi confecţionării calapoadelor pentru încălţăminte.

Utilizând instrumente specifice aplicaţiei CRIPIN Dynamics CAD SUITE, modulul Model Tracer şi Last Maker, în această lucrare este prezentată o metodă pentru elaborarea de noi calapoade.

Metoda pentru crearea de noi calapoade poate fi utilă producătorilor de încălţăminte care pot găsi oricând un calapod potrivit conceptului de produs. 


\section{REFERENCES}

1. Costea, M., Drişcu, M, Crispin Dynamics 3D - New solution for shoemakers creating and modification of the shoe last, Revista de Pielarie Incaltaminte (Leather and Footwear Journal), 2011, 11, 2, 109-120, ISSN 1583-4433.

2. Mihai, A., Costea, M. et al., Customized footwear inserts for high arched foot-one case study, Proceedings of the 3rd International Conference on Advanced Materials and Systems - ICAMS 2010, 16-18 September 2010, Bucharest.

3. Drişcu, M., Modelling flat and 3D footwear shapes (in Romanian), 2008, Pim Press, laşi.

4. Drişcu, M., Reconstruction and flattening of the surface shoe last, Proceedings of The 14th International Conference, laşi\&Chişinău ModTech2010, May 2010, Romania, ISSN:2006-391.

5. Drişcu, M., Harnagea, F., Crispin Dynamics Engineer an Instrument for Making the Footwear Parts, Quality management in higher education, Proceedings of The 5Th International Seminar on the Quality Management in Higher Education, 12-14 June 2008, Tulcea, Romania.

6. Drişcu, M., Mihai, A., Approximating the cloud of the shoe last point by a set of developable stripes, TMCR, lasi, 2008.

7.http://www.google.ro/search?q=shoe+size\&hl=ro\&prmd=imvns\&tbm=isch\&tbo=u\&source=univ\&sa=X\&ei=KIpTT 4DwNaik4ATx7rGzDQ\&sqi=2\&ved=0CEkQsAQ\&biw=1024\&bih=515, accessed on 08.04.2013.

8. http://www.footwear-cadcam.com/languages/fr/general/cadsuite.asp, accessed on 08.04.2013. 